\title{
The Extensible Business Reporting Language and Fraudulent Financial Statement in Indonesia
}

\author{
Desya Puspa Wijaya ${ }^{1}$, Diah Hari Suryaningrum ${ }^{2}$ \\ \{puspadesya22@gmail.com ${ }^{1}$, diah.suryaningrum.ak@upnjatim.ac.id² \\ UPN Veteran Jawa Timur, Surabaya, Indonesia ${ }^{12345}$
}

\begin{abstract}
This study aims to prove the effectiveness of the implementation of Extensible Business Reporting Language (XBRL) on the level of fraudulent financial statements. The sample was determined by using purposive sampling method and obtained 81 companies as the research sample. The results showed that XBRL with the SIZE control variable affected financial statement fraud. In contrast, the control variables DAR, ROA, GDP, and PBV did not support the effect of XBRL on financial statement fraud. The test results also prove that there are differences before and after implementing XBRL, where the measurement of financial statement fraud is lower after the application of XBRL. This result means that the implementation of XBRL will force companies to provide accountable and transparent information. The business and financial information collected in XBRL is a machine format reading and operation, thereby increasing the ease of dissemination and public analysis, thus making it easier to detect fraudulent financial statements.
\end{abstract}

Keywords: Extensible Business Reporting Language (XBRL), Firm Size, Fraudulent Financial Statement

\section{Introduction}

The increase in the number of capital market investors will be in line with the increasing need for information. Complete information can be obtained from the company's financial statements. Investors are looking for profit information. A rising or stable profit will look more attractive. Not a few companies do various ways to enhance profits. Erick Tohir [1], said that many BUMNs are doing window dressing. This act can be categorized as a criminal act. Several cases of fraud that occurred among them were PT Asuransi Jiwasraya, which reported false profit since 2006, as well as allegations of corruption in it [2]. The OJK sanctioned PT Hanson (MYRX) for not disclosing PPJB to its auditors, resulting in material overstated income [3], Garuda Indonesia's net profit is considered odd. Gains were obtained, thanks to soaring other operating income of U.S. \$ 306.88 million [4], and Bank Bukopin modified credit card data. These frauds cause commission-based income to increase inappropriately [5].

According to The Association of Certified Fraud Examiners [6], financial statement fraud is an act of deliberate misstatement of material in the financial statements of an organization. Fraudulent actions in financial reporting can be caused by pressures and expectations of performance [7]. The efforts made by the Indonesia Stock Exchange to minimize this problem is by developing a reporting system based on Extensible Business Reporting 
Language (XBRL). Extensible Business Reporting Language is digital-based reporting using a reporting language that can be authorized; the terms and explanations contained in XBRL will make it easier for users to understand financial information more efficiently. Users also find it easier to analyze financial reports [8].

IDX is aggressively developing XBRL, so that June 22, 2015, the system has been launched to the public. The planned technology is to integrate XBRL with a listed company reporting system, namely, IDXnet [9]. According to the Indonesia Stock Exchange [10], XBRL has benefits, such as increasing information disclosure, being able to improve information services, and making it easier to collect issuers' reporting data so that information is more reliable. This research is essential because, in Indonesia, no similar study has been conducted. Besides, the problem of fraudulent financial statements seems to be a polemic so that the chain must be broken slowly. Researchers are interested in doing this research because XBRL is relatively new in Indonesia. Researchers want to prove the role of $\mathrm{XBRL}$ in reducing fraudulent financial statements.

\section{Theoretical Review}

\subsection{Agency Theory}

Agency theory [11], discusses there is a contract between the agent (management) and the principal (shareholder) in which the agent receives the mandate to manage the company from the principal. On the basis of personal interest, the agent can take action which leads to fraudulent financial statements to beautify company profits. When able to cheat, the agent benefits from this practice in the form of a bonus. Differences in interests caused by information gaps can lead to bigger problems with increasingly uncontrollable fraud, the most common in the form of earnings management.

Based on agency theory, information gaps are also an opportunity for an agent to act fraudulently to benefit themselves. When fraudulent financial statements occur, it will have an impact on many parties. The perpetrators must bear some consequences, the community will also lose trust, and the worst thing that will happen to a company in bankruptcy [12]. Financial statement fraud that often occurs is often in the form of earnings management. Ruiz [13] suggested that fraudulent financial statements such as earnings management arise because of several motivations in a manager, such as the desire to get a bonus, compensation or other personal gains.

\subsection{Extensible Business Reporting Language (XBRL)}

XBRL [14], is digital-based reporting using language authorized financial reporting. XBRL uses a format similar to XML and HTML which contains taxonomies of financial databases. XBRL is operated through access to software. The main purpose of XBRL is how business data or information can be exchanged, compared, and used without language barriers and accounting standards. Several researchers have studied the role of XBRL, such as Leow [15] investigate the impact of XBRL adoption on earnings management. The same research was conducted Kaidi [16], testing the effect of XBRL in reducing discretionary accruals for companies that are required to use the XBRL format. The results are proof that discretionary accruals decrease after implementing XBRL.

Kaidi's research provides direction, to pay attention to company discretionary accruals in calculating earnings management that proxies fraudulent financial statements. Also, studies 
Kim et al. [17] comparing the size of discretionary accruals in the adopted XBRL quarter with the non-adopted quarter. The study found discretionary accruals decreased in the postXBRL adoption period. Other findings also prove XBRL can improve reporting comparability. Liu et al. [18] examined XBRL from another perspective by reviewing the application of XBRL to the information asymmetry of Belgian companies. The results show that the information asymmetry is decreasing and there is an increase in liquidity in the company. Based on agency theory and previous research, the formulation of the research hypothesis is:

H1: The application of XBRL affects fraudulent financial statements

$\mathrm{H} 2$ : There are differences in financial statement fraud before and after implementing XBRL

\section{Research Method}

The data in this study financial reports of related companies. Data were obtained from the official website of the Indonesia Stock Exchange (www.idx.co.id), and the company's official website. The type of data, secondary data in the form of financial reports. The population of this research is 674 companies, and 81 companies were obtained as the research sample, through purposive sampling technique. The research object is something that will be used as material research. The research object in this study was fraudulent financial statements, while the research subjects were all variables used in the study.

The data is divided into two parts, namely three years before (2012-2014) and three years after the implementation of XBRL (2016-2018). Financial statement fraud will be proxied through earnings management. The earnings management model used is the Modified Jones Model. The influence of the XBRL variable on Financial Statement Fraud is supported by the existence of 5 control variables in the form of firm size (SIZE), return on assets (ROA), debt to asset ratio (DAR), gross domestic product (GDP), and price to book value (PBV). This study uses multiple linear regression analysis techniques with the help of SPSS software. To test the hypotheses, if the significant value is $<5 \%$, then the hypotheses are accepted.

\section{Results and Discussion}

The classical assumption test is carried out to ensure that the data for multiple linear regression are for Best Linear Unbiased Estimator (BLUE).

\subsection{Analysis and Hypothesis 1 Regression}

The model fit test was used to assess the suitability of the research regression model in Table 1.

Table 1. Model Fit Test Results and Coefficient of Determination

\begin{tabular}{lllll}
\hline Model & F & Sig. & $\mathbf{R}^{\mathbf{2}}$ & Std Error \\
\hline Regression 1 & 5.823 & $.016^{\mathrm{b}}$ & .014 & .00034 \\
Regression 2 & 3.050 & $.010^{\mathrm{b}}$ & .046 & .00147 \\
\hline
\end{tabular}

Source: Processed data (2020) 
The results of the goodness of fit test for regression models 1 and 2 showed a significance value of 0.016 and $0.010<0.05$. The calculated $\mathrm{F}$ value $=5.823$ and $3.050>\mathrm{F}$ table $=3.86$ and 2.12. It can be concluded that the XBRL variable $(\mathrm{X})$ and the control variable can be used to predict financial statement fraud (Y). The results of the coefficient of determination (R2) show that only $4.6 \%$ of the application of XBRL, Size, ROA, DAR, PBV, and GDP can predict financial statement fraud. The rest is explained by other variables not discussed in this study.

Table 2. Estimation of Multiple Linear Regression Model and Hypothesis Test

\begin{tabular}{llllll}
\hline Variabeles & $\mathrm{B}$ & Std. Error & $\mathrm{t}$ & Sig. & Conclusion \\
\hline (Constant) & 0.031 & 0.004 & 8.457 & & \\
XBRL $(\mathrm{X})$ & -0.001 & 0 & -2.324 & 0.021 & Accepted \\
SIZE & 0.001 & 0 & 2.084 & 0.038 & Accepted \\
ROA & -0.003 & 0.002 & -1.369 & 0.172 & Rejected \\
DAR & -0.005 & 0.001 & -0.626 & 0.532 & Rejected \\
PBV & -4.527 & 0 & -0.636 & 0.532 & Rejected \\
GDP & -2.881 & 0 & -1.595 & 0.111 & Rejected \\
\hline
\end{tabular}

Dependent variable: Fraudulent Financial Statement (Y)

Source: Processed data (2020)

Based on the results in table 2, the regression equation is:

$\mathrm{Y}$ or $\mathrm{DA}=0.21+-0.001 \mathrm{XBRL}$

Regression 1

$\mathrm{Y}$ or DA $=0,31+-0,001 \mathrm{XBRL}+0,001 \mathrm{SIZE}+-0,005 \mathrm{DAR}+-4,527 \mathrm{PBV}+-0,003 \mathrm{ROA}+$ $(-2,881)$ GDP. Regression 2

The application of XBRL affects fraudulent financial statements (H1 is accepted), with the XBRL coefficient being minus, meaning that the implementation of XBRL will cause a decrease in financial statement fraud). The only control variable that affects financial statement fraud is the firm size (SIZE).,

\subsection{Analysis of Hypothesis 2 Paired T-Test}

Paired T-Test or different test is used to test whether there is a difference in the two paired data. The requirement for a different test is that the data must be normally distributed first. This difference test is carried out only on the XBRL variable $(\mathrm{X})$ and financial statement fraud $(\mathrm{Y})$ by not including the control variable because the objective is to prove the difference before and after the implementation of XBRL. Based on table 3, the sig (2-tailed) value of $0.000<0.05$ from these results indicates that there are differences in financial statement fraud for three years (2012-2014) before and three years (2016-2018) after applying and $\mathrm{H} 2$ is accepted. The positive mean value is 0.4796 , which means that there is a decrease in fraudulent financial statements after implementing XBRL.

Table 3. Paired T-Test Results

\begin{tabular}{llllll}
\hline & Mean & Std Error Mean & t & Sig. & Conclusion \\
\hline Pair1 before - after & .4796 & .0227 & 21.106 & 0.000 & Accepted \\
\hline \multicolumn{2}{l}{ Source: Processed data (2020) } & & & &
\end{tabular}




\subsection{The effect of XBRL application on fraudulent financial statements}

The results of hypothesis testing prove that there is an effect of XBRL application on financial statement fraud proxied by earnings management. Besides, of the five control variables in this study (SIZE, DAR, ROA, PBV, and GDP), only the control variable Size affects financial statement fraud. Chen [19] revealed that XBRL would increase the accountability and transparency of business and financial information. Better accountability and transparency will reduce the level of fraudulent financial statements. Fraudulent financial statements through accounting policies can be made by utilizing accrual accounts. According to agency theory [20], the difference in interests between the principal and the agent causes the agent to try to make accounting policies that will benefit the agent. Accrual management motivation is grouped into opportunistic and signalling motives. Opportunistic motivation encourages management to present financial reports (especially earnings reports) higher than they are. Whereas in signalling motivation, management tends to manage accruals which leads to earnings persistence. This result can be done by improving the quality of financial reports through accounting numbers that lead to earnings quality. XBRL implementation reduces the risk of fraudulent financial statements.

This result is in line with the research conducted by Kaidi [16] and Kim et al. [17], which supports this research. XBRL gives a pretty good effect in minimizing earnings management actions by reducing discretionary accruals. Leow [15] also stated that companies that implement XBRL experience a decrease in the level of earnings management because the company's discretionary accruals decline. When XBRL can reduce the level of fraudulent financial statements, the information gap between the agent and the principal will also be reduced. Thus, there will be better information exchange if information asymmetry can be overcome through the application of XBRL.

4.4 Differences of fraudulent financial statements before and after implementing XBRL

The paired T-test results show that there are differences in fraudulent financial statements before and after implementing XBRL. The positive mean value indicates that financial statement fraud before the implementation of XBRL is higher than financial statement fraud after XBRL. Several indicators of risk that can trigger fraudulent financial statements include the recording of more bad debts in a profitable year. The company lost market share and reduced its bad debt expense in the loss year to smooth profit. The company is less profitable than its competitors - the accounting policies that generate relatively high income. The company is experiencing temporary performance problems and low taxable income accounting policy with a high proportion of off-balance sheet transactions. Frequent changes in auditors or delays in issuing financial statements [21], These risks can be reduced by implementing XBRL. The business and financial information collected in the XBRL format is machine-readable and operable, thereby increasing the ease of dissemination and public analysis to determine whether there is a fraud.

The results of this study are supported by research conducted by Kim et al. [17], that states that the post XBRL period has a lower discretionary accrual rate than the pre-XBRL implementation period. Liu et al. [18] prove XBRL can reduce earnings management by reducing the company's discretionary accruals. Also, XBRL can reduce information asymmetry so that it can minimize an agent acting fraudulently or harming the principal and other parties. 


\section{Conclusions}

The research results prove that the application of Extensible Business Reporting Language (XBRL) has a negative effect on fraudulent financial statements. The more the company implemented XBRL, the lesser the fraudulent financial reporting. There are differences in fraudulent financial statements before and after implementing XBRL. The fraudulent financial statement is higher before than after the implementation of XBRL Even though the empirical result of this study supports the hypotheses, at least two limitations should be carefully considered. First, the data were collected only in Indonesia that may have different capital market characteristics with other countries.

These differences may include the capital market regulation, economics condition, tax law, or investment opportunity. Hence, the present result should not be assumed to represent the general case in the world. However, this study may provide a primary reference for other countries whose environment and type of industries are similar to those in Indonesia. Second, even though this study controls the hypothesis testing with five control variables, the result indicates that these control variables may not influence the relationship among variables. Only one control variable (SIZE) can change the effect.

\section{References}

[1] S. Ferry, "Erick: BUMN Suka 'Mempercantik' Lapkeu, Bisa Masuk Kriminal!," 2020 [Online]. Available: https://www.cnbcindonesia.com/market/20200110094444-17129058/erick-bumn-suka-mempercantik-lapkeu-bisa-masuk-kriminal.

[2] S. Makki, "Kronologi Kasus Jiwasraya, Gagal Bayar Hingga Dugaan Korupsi," 2020. [Online]. Available: https://www.cnnindonesia.com/ekonomi/20200108111414-78463406/kronologi-kasus-jiwasraya-gagal-bayar-hingga-dugaan-korupsi.

[3] A. Wicaksono, "Sulap Lapkeu, Mantan Dirut Hanson International Didenda Rp5 M," 2019. [Online]. Available: https://www.cnnindonesia.com/ekonomi/20190809145515-92419879/sulap-lapkeu-mantan-dirut-hanson-international-didenda-rp5-m.

[4] H. R. Pratiwi, "Kronologi Kisruh Laporan Keuangan Garuda Indonesia," 2019. [Online]. Available: https://www.cnnindonesia.com/ekonomi/20190430174733-92-390927/kronologikisruh-laporan-keuangan-garuda-indonesia.

[5] F. F. Rachman, "Bank Bukopin Permak Laporan Keuangan, Ini Kata BI dan OJK," 2018 [Online]. Available: https://finance.detik.com/moneter/d-3994551/bank-bukopin-permaklaporan-keuangan-ini-kata-bi-dan-ojk.

[6] Association of Certified Fraud Examiners (ACFE), "Report to the nations on occupational fraud and abuse on occupational fraud and abuse," 2014. [Online]. Available: https://www.scribd.com/document/233877975/Www-acfe-Mexico-com-Mx- Archivos-2014Report-to-Nations.

[7] D. Priantara, Fraud Auditing \& Investigation, 1st ed. Mitra Wacana Media, 2013.

[8] XBRL International Inc, "An Introduction to XBRL." [Online]. Available: https://www.xbrl.org/the-standard/what/an-introduction-to-xbrl/.

[9] R. Astria, "BEI Luncurkan Sistem Pelaporan Emiten Berbasis XBRL," 2015. [Online]. Available: $\quad$ https://market.bisnis.com/read/20150622/7/445822/bei-luncurkan-sistempelaporan-emiten-berbasis-xbrl.

[10] Bursa Efek Indonesia, "XBRL," 2018. [Online]. Available: https://idx.co.id/perusahaantercatat/xbrl/. [Accessed: 20-Sep-2011].

[11] M. Jensen and W. Meckling, "Theory of the Firm: Managerial Behavior, Agency Costs and Ownership Structure," J. financ. econ., 1976.

[12] A. W. Manggau, "Pengaruh Asimetri Informasi Dan Ukuran Perusahaan Terhadap Manajemen Laba Pada Perusahaan Pertambangan Yang Terdapat Di Bursa Efek Indonesia," 
AKUNTABEL J. Ekon. dan Keuang., vol. 13, no. 2, pp. 103-114, 2016.

[13] C. V. Ruiz, "Literature review of earnings management: Who, why, when, how and what for ?," Finnish Bus. Rev., pp. 1-13, 2016.

[14] E. K. Ghani, J. Said, and K. Muhammad, "Enhancing Corporate Governance via XBRL: Preparers' Perception on Compatibility Expectation,” Procedia - Soc. Behav. Sci., vol. 145, pp. 308-315, 2014.

[15] X. C. Leow, "The Impact of XBRL on Earnings Management," no. August, pp. 1-72, 2012. [Online].

Available: https://www.softwarepakketten.nl/upload/xbrl/2014_Xian_Cheng_Leow_MASTER_THESIS XBRL_EarningsManagement_XC_14082012_v2.pdf.

[16] W. Kaidi, "Does XBRL reduce the level of earnings management ?," pp. 1-57, 2015. [Online]. Available: https://scripties.uba.uva.nl/download?fid $=635269$.

[17] J. B. Kim, J. W. Kim, and J. H. Lim, "Does XBRL Adoption Constrain Earnings Management? Early Evidence from Mandated U.S. Filers," Contemp. Account. Res., vol. 36, no. 4, pp. 2610-2634, 2019.

[18] C. Liu, X. (Robert) Luo, and F. L. Wang, "An empirical investigation on the impact of XBRL adoption on information asymmetry: Evidence from Europe," Decis. Support Syst., vol. 93, no. 2017 , pp. 42-50, 2017.

[19] Y. Chen, "A comparative study of e-government XBRL implementations: The potential of improving information transparency and ef fi ciency," Gov. Inf. Q., vol. 29, no. 4, pp. 553563, 2012.

[20] P. Company, C. Jensen, and H. Meckling, "Theory of The Firm: Managerial Behavior , Agency Costs and Ownership Structure,” vol. 3, pp. 305-360, 1976.

[21] D. M. Boyle, J. F. Boyle, and B. W. Carpenter, "The SEC's Renewed Focus on Accounting Fraud: Insights and Implications for Auditors and Public Companies," CPA J., no. February, pp. 68-72, 2014. 